\title{
Carbonate dissolution in the turbid and eutrophic Loire estuary
}

\author{
Gwenaël Abril $^{1, *}$, Henri Etcheber ${ }^{1}$, Bruno Delille $^{2}$, Michel Frankignoulle $^{2}$ \\ Alberto V. Borges ${ }^{2}$ \\ ${ }^{1}$ Département de Géologie et Océanographie, Université Bordeaux 1, CNRS-UMR EPOC 5805, avenue des Facultés, \\ 33405 Talence, France \\ ${ }^{2}$ Unité d'Océanographie Chimique, Institut de Physique (B5), Université de Liège, 4000 Sart Tilman, Belgium
}

\begin{abstract}
We measured particulate and dissolved organic carbon (POC and DOC), chlorophyll, oxygen, partial pressure of $\mathrm{CO}_{2}, \mathrm{pH}$, total alkalinity (TAlk) and particulate inorganic carbon (PIC) during a late summer cruise in the eutrophic Loire estuary. These parameters reveal an intense mineralisation of organic matter in the estuarine maximum turbidity zone (MTZ) that results in oxygen deficits (down to $20 \%$ of the saturation level) and high $\mathrm{CO}_{2}$ oversaturations ( $\mathrm{pCO}_{2}$ up to $2900 \mu \mathrm{atm}$ ). Several facts revealed the occurrence of carbonate dissolution in the Loire MTZ: large amounts of alkalinity were produced in the upper estuary, increasing its transfer to the ocean by $30 \%$; the calculated saturation index showed a net undersaturation for aragonite and a slight undersaturation for calcite in the MTZ; and PIC decreased from $2.1 \%$ (\% dry weight) in riverine suspension to $0.4 \%$ in the MTZ. A stoichiometric approach is used to assess the coupling between aerobic respiration and carbonate dissolution, where apparent oxygen utilisation, excess $\mathrm{CO}_{2}$, TAlk and dissolved inorganic carbon are compared quantitatively. About $20 \%$ of the $\mathrm{CO}_{2}$ generated by respiration was involved in carbonate dissolution. The loss of PIC at the river-estuary transition quantitatively corresponds to the amount of authigenic calcite precipitated upstream in the highly eutrophic river. This suggests that $\mathrm{CO}_{2}$ exchange with the atmosphere along the eutrophic river-estuary continuum is buffered by carbonate precipitation in the autotrophic river and its dissolution in the heterotrophic estuary.
\end{abstract}

KEY WORDS: Eutrophication - Estuarine turbidity maxima $\cdot$ Heterotrophy $\cdot$ Aerobic respiration · Carbonate dissolution

Resale or republication not permitted without written consent of the publisher

\section{INTRODUCTION}

Estuaries play an important role in the transfer of material from the land to the coastal ocean. This is particularly true for macrotidal estuaries, where the long residence times of both water and suspended matter allow a significant modification in the speciation of chemical compounds by biological activity and physico-chemical processes (e.g. Wollast 1983). The transport of carbon by world rivers is a significant component of the global carbon cycle estimated to ca. $0.9 \mathrm{GtC} \mathrm{yr}^{-1}$, of which $\sim 60 \%$ is inorganic and $40 \%$ is organic (Meybeck 1993a). It is now well established that estuaries are net heterotrophic ecosys- tems, where total respiration exceeds gross primary production (Smith \& Hollibaugh 1993, Gattuso et al. 1998). This respiration is particularly intense in the upper part of estuaries, which generally coincides with the maximum turbidity zone (MTZ), and where oxygen deficits, $\mathrm{CO}_{2}$ super-saturations and $\mathrm{CO}_{2}$ fluxes to the atmosphere are highest (Thouvenin et al. 1994, Frankignoulle et al. 1996, 1998, Cai et al. 1999, Raymond et al. 2000). Most of the riverine organic carbon respired in estuaries enters in the particulate form (POC) and originates from soils, freshwater phytoplankton and sewage (Ittekkot \& Laane 1991, Abril et al. 2002). On the contrary, riverine dissolved organic carbon (DOC) appears more refractory 
to bacterial degradation, DOC having a conservative behaviour (Mantoura \& Woodward 1983) or sometimes being produced in the estuarine zone (Raymond \& Bauer 2001).

By contrast to organic carbon, little is known about how estuarine processes could change the net fluxes of inorganic carbon between the land and the ocean. Respiration produces dissolved inorganic carbon (DIC) as $\mathrm{CO}_{2}$ that rapidly escapes to the atmosphere from the estuary itself or from the adjacent coastal area (Frankignoulle et al. 1996, 1998, Cai et al. 1999, Borges \& Frankignoulle 2002). Total alkalinity (TAlk), which is not affected by atmospheric exchange and is weakly affected by aerobic respiration (only through associated ammonification; Brewer \& Goldman 1976), has often been considered as a conservative parameter during estuarine mixing (Hoppema 1990). Recently, net changes in TAlk have been reported in relation to different estuarine biogeochemical processes: (1) in the highly polluted Scheldt estuary, ammonification and denitrification on the one hand and nitrification on the other hand, respectively, consume and produce enough protons to significantly affect the alkalinity (Frankignoulle et al. 1996, Abril \& Frankignoulle 2001); (2) in estuaries with large tidal marshes, significant amounts of alkalinity were found to be produced by denitrification (Cai et al. 2000) and/or sulfate reduction, when coupled to a net accumulation of sulfides in sediments (Brasse et al. 1999, Cai et al. 1999, Raymond et al. 2000); (3) in the highly turbid Ems and Gironde estuaries, dissolution of calcium carbonate occurs in MTZs, generating alkalinity (de Jonge \& Villerius 1989, Abril et al. 1999). Here, we report significant carbonate dissolution also in the Loire estuary, where, in addition, due to a pronounced eutrophication in freshwaters, authigenic carbonate constitutes a significant fraction of the riverine suspensions entering the estuary (Grosbois et al. 2001).

\section{MATERIALS AND METHODS}

Study area. The Loire estuary (Fig. 1) on the French Atlantic coast is $100 \mathrm{~km}$ long with a surface area of $100 \mathrm{~km}^{2}$, an average depth of $9 \mathrm{~m}$ and a restricted area of tidal flats. The estuary is macrotidal (average tidal amplitude at the mouth $\sim 4 \mathrm{~m}$ ), well mixed and highly turbid. The MTZ (defined as depth-integrated suspended particulate matter (SPM) $>1 \mathrm{~g} \mathrm{l}^{-1}$ ) is 20 to $50 \mathrm{~km}$ long, depending on river discharge (Gallene 1974). In the MTZ, surface SPM concentrations can reach $2 \mathrm{~g} \mathrm{l}^{-1}$ during spring tide, but decrease to a few hundred $\mathrm{mg} \mathrm{l}^{-1}$ during neap tides, when suspensions are temporarily trapped in fluid mud layers (Le Normant 2000). Long-term budget calculations show that river input is by far the major source of suspensions to the estuary, residence times of waters and suspensions being, respectively, 10 to $30 \mathrm{~d}$ and 1 to $2 \mathrm{yr}$ (Migniot 1993).

The Loire River, which drains a $117000 \mathrm{~km}^{2}$ area, has an average discharge of $850 \mathrm{~m}^{3} \mathrm{~s}^{-1}$. It is probably one of the most eutrophic large rivers in the world, with chl a concentrations exceeding $100 \mu \mathrm{g} \mathrm{l}^{-1}$, and algal POC representing $60 \%$ of the POC in summer (Meybeck et al. 1988). In addition to a high load of algal POC, a second effect of eutrophication in the Loire River is the chemical precipitation of authigenic carbonates in the river waters, when primary production raises the $\mathrm{pH}$ above 8.5 (Manickam et al. 1985). As a consequence, authigenic carbonates represent up to $37 \%$ of the river suspensions in summer (Meybeck et al. 1988, Grosbois et al. 2001). Previous studies have shown that the estuarine zone is highly heterotrophic (Relexans et al. 1988), with all the riverine algal POC being mineralised in the MTZ, where in addition light penetration is too low to sustain important primary production (Billen et al. 1986, Meybeck et al. 1988). As a result, the estuarine waters in the MTZ are dramatically oxygen depleted (Thouvenin et al. 1994).

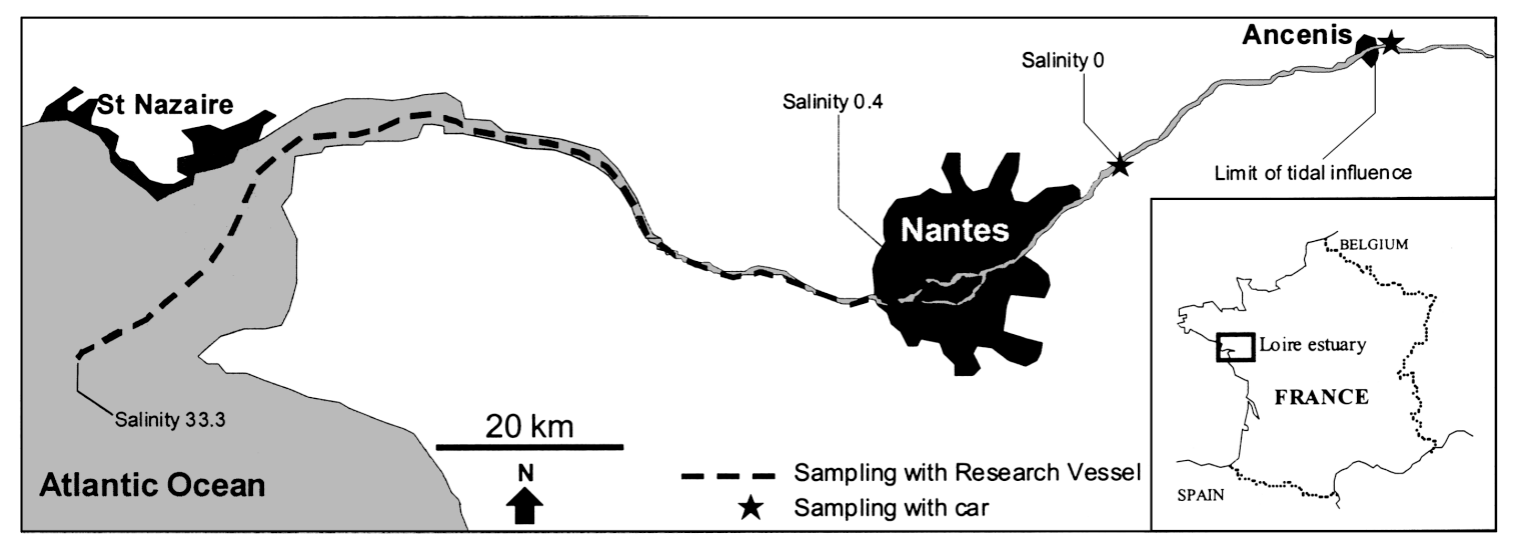

Fig. 1. Map of the Loire estuary with different sampling strategies 
Sampling and analytical techniques. During a $5 \mathrm{~d}$ cruise in spring-tide conditions, from 10 to 14 September 1998, we sampled surface waters along the whole salinity gradient of the estuary, including a non-tidal river station upstream of Ancenis, a freshwater tidal station upstream from the city of Nantes and a marine station downstream at salinity 33.3 (Fig. 1). We measured salinity and temperature with a Sea Bird Electronics (SBE) 19 probe. Chl a was determined on glass fibre filters (porosity $0.7 \mu \mathrm{m}$ ) by fluorescence after extraction in $90 \%$ acetone (precision $\pm 10 \%$ ). Two precombusted and pre-weighed glass fibre filters (porosity $0.7 \mu \mathrm{m}$ ) were used for SPM determination (reproducibility $\pm 15 \%$ ); one filter was then used for total carbon determination with a LECO analyser; the second filter was acidified with $\mathrm{HCl} 2 \mathrm{~N}$ to remove carbonate and then analysed for POC (precision $\pm 5 \%$ ). Particulate inorganic carbon (PIC) was determined as the difference between the total carbon and the organic carbon contents of the suspensions, and expressed as percent of total suspended matter (precision $\pm 10 \%$ ). We measured $\mathrm{pH}$ with a Ross combination electrode calibrated against NBS buffers (precision $\pm 0.005 \mathrm{U}$ ), TAlk by Gran electrotitration (precision $\pm 4 \mu \mathrm{Eq} \mathrm{kg}{ }^{-1}$ ) and oxygen with an automated Winkler method $\left( \pm 2 \mu \mathrm{mol} \mathrm{kg}{ }^{-1}\right)$. We calculated the surface partial pressure of $\mathrm{CO}_{2}\left(\mathrm{pCO}_{2}\right)$ and DIC from temperature, salinity, $\mathrm{pH}$ and TAlk with the constants from Mehrbach et al. (1973) and Lyman (1975), and the $\mathrm{CO}_{2}$ solubility coefficient from Weiss (1974). We also calculated the excess

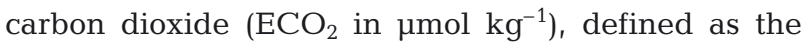
quantity of DIC that must be released as $\mathrm{CO}_{2}$ to the atmosphere to achieve complete air-water equilibration. $\mathrm{ECO}_{2}$ was calculated as the difference between the in situ DIC and the DIC computed at the atmospheric equilibrium of $370 \mu \mathrm{atm}$ and using the in situ TAlk. Oxygen concentrations were compared with the oxygen concentration of air-saturated water computed with the algorithm of Benson \& Krause (1984), apparent oxygen utilisation (AOU) being the difference between the 2 oxygen concentrations. Finally, we estimated the saturation index $(\Omega)$ of calcite and aragonite, using the solubility coefficients given by Mucci (1983) and, as a first approximation, by considering conservative mixing for $\mathrm{Ca}^{2+}$ between the Loire River (September average: $0.9 \mathrm{mmol} \mathrm{kg}^{-1}$; Grosbois et al. 2000) and the sea (10 mmol kg${ }^{-1}$; Morse \& Mackenzie 1990).

\section{RESULTS}

The distributions of POC, DOC and chl a (Fig. 2) were very consistent with the ones measured in the 1980s (Meybeck et al. 1988, Relexans et al. 1988). During our cruise, the MTZ was divided in 2 parts
(Fig. 2A), one between salinities 0 and 10 and a second between salinities 14 and 18, where SPM at the surface were $>100 \mathrm{mg} \mathrm{l}^{-1}$ and where fluid-mud layers (height $\sim 50 \mathrm{~cm}$ ) could be observed using an echo sounder. In between, around salinity 12, surface waters were less turbid and no fluid mud was detected. POC (Fig. 2A) and chl a (Fig. 2B) were exceptionally high at the nontidal river station and rapidly decreased at the entrance of the estuarine MTZ. The \% POC stabilised in the MTZ, at a constant value of $3.5 \%$, and chl a decreased to less than $2 \mu \mathrm{g} \mathrm{l}^{-1}$ at the estuarine mouth. DOC decreased almost linearly with salinity (Fig. 2B), although some significant peaks at salinities 0,13 and 20 suggest some input, possibly related to episodic resuspensions of anoxic fluid-mud (Abril et al. 1999). Although the river was rich in chlorophyll, the water remained supersaturated in $\mathrm{CO}_{2}$ and below the saturation level for oxygen (Fig. 3), either due to a decay of the freshwater phytoplankton bloom during this late summer period and/or inputs from groundwaters (Jones \& Mulholland 1998). In the estuary, the distributions of oxygen and $\mathrm{pCO}_{2}$ showed a remarkable antiparallelism along the salinity gradient (Fig. 3). In the 2 most turbid regions (salinity 0 to 10 and 14 to 23 ),

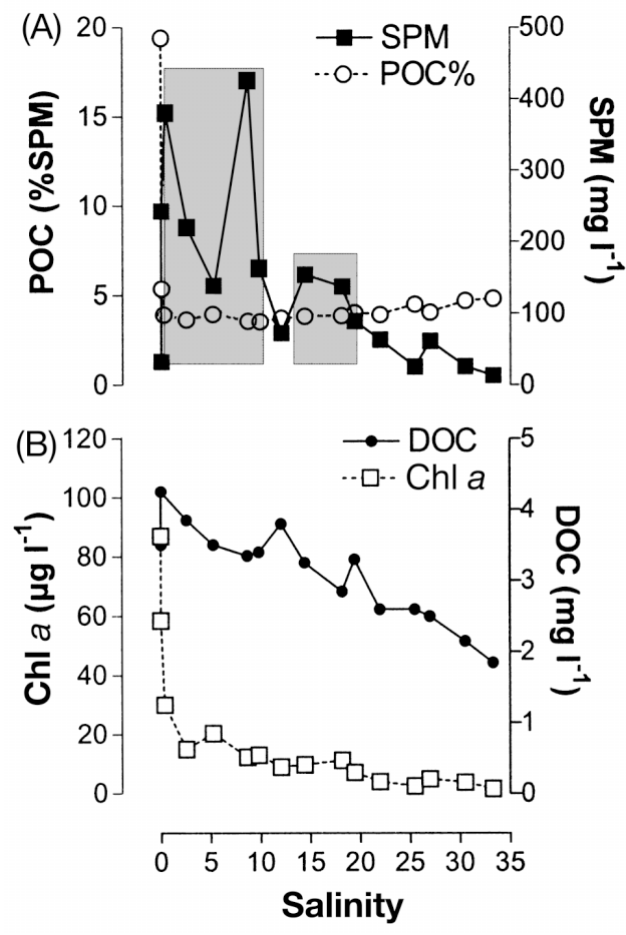

Fig. 2. Distributions of (A) suspended particulate matter $\left(\mathrm{SPM}_{i} \mathrm{mg} \mathrm{l}^{-1}\right.$ ) and particulate organic carbon $\left(\mathrm{POC}_{i} \% \mathrm{SPM}\right)$; (B) chl a $\left(\mu \mathrm{g} \mathrm{l}^{-1}\right)$ and dissolved organic carbon (DOC; $\mathrm{mg} \mathrm{l}^{-1}$ ) as a function of salinity in the Loire estuary in September 1998. Shaded areas indicate the 2 regions of the estuarine maximum turbidity zone (MTZ) 


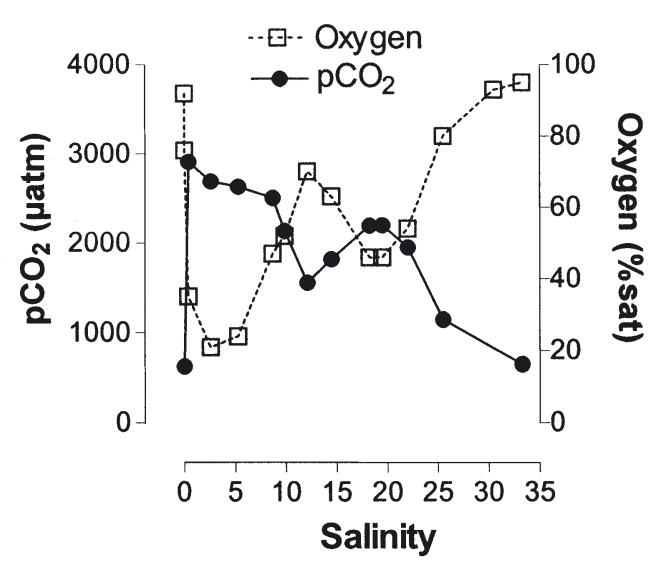

Fig. 3. Distributions of oxygen (\% saturation) and partial pressure of $\mathrm{CO}_{2}\left(\mathrm{pCO}_{2} ; \mu \mathrm{atm}\right)$ as a function of salinity in the Loire estuary in September 1998

$\mathrm{pCO}_{2}$ showed a maximum and oxygen a minimum. The decrease of POC and chl $a$ at the river-estuary transition, and the oxygen depletion and $\mathrm{CO}_{2}$ supersaturation in the estuarine MTZ, attest for the marked heterotrophy in the eutrophic Loire estuary (Relexans et al. 1988).

DIC showed a strong non-conservative behaviour, with a steep increase between the river and salinity 0.5 (Fig. 4A). Most of this DIC increase was related to the production of alkalinity at the entrance of the MTZ (Fig. 4B). In parallel, PIC rapidly dropped from $2.1 \%$ in river suspensions to a constant value of $0.4 \%$ in the MTZ suspensions (Fig. 4C), except at salinity 12, where a small PIC peak occurs, probably due to a local precipitation because $\mathrm{pH}$ (not shown) re-increased at that location or to grain-size effects associated with the physical mixing of different suspensions. River waters were largely oversaturated with respect to calcite $(\Omega=5.7)$ and aragonite $(\Omega=3.2)$ (Fig. 4 C). By contrast, estuarine waters were largely undersaturated for aragonite ( $\Omega=0.56 \pm 0.11$ in the 0 to 22 salinity range) and close to equilibrium for calcite $(\Omega=1.11 \pm 0.19$ in the 0 to 22 salinity range), with a slight undersaturation (3 $\Omega$ values $<1$ for calcite between the 2.5 and 9 salinity range) (Fig. $4 \mathrm{C}$ ). This suggests that the thermodynamic conditions required for some carbonate dissolution are locally reached in the estuary.

\section{DISCUSSION}

\section{Evidence for carbonate dissolution}

When comparing the observed riverine TAlk concentration with the intercept at zero salinity of the line tangent to the curve at high salinities (Fig. 4A), ca.
$720 \mu \mathrm{Eq} \mathrm{kg}{ }^{-1}$ of TAlk were generated in the Loire estuary during our cruise, apparently in the region with salinity $<12$. This corresponds to an increase of $~ 35 \%$ in the net alkalinity flux to the Atlantic Ocean, where it will enter into the oceanic carbonate precipitation/dissolution cycle (Morse \& Mackenzie 1990). The distribution of dissolved inorganic nitrogen species during our cruise can be seen in Middelburg \& Nieuwenhuize (2001). Nitrate decreased linearly from $70 \mu \mathrm{M}$ in the river to $10 \mu \mathrm{M}$ at sea, showing that denitrification was not significant at the estuarine scale, nor were presumably other anaerobic, alkalinity-generating processes such as sulphate reduction. In addition, ammonium was below $10 \mu \mathrm{M}$ all along the salinity gradient, rejecting the possibility of significant alkalinity changes due

(A)

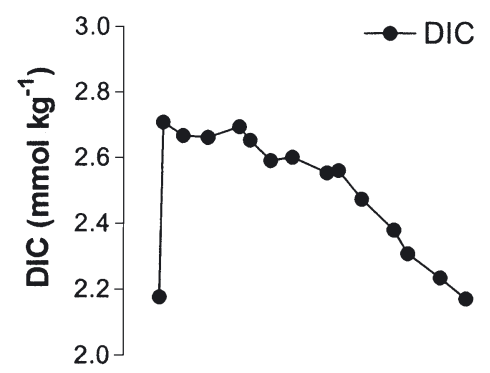

(B)

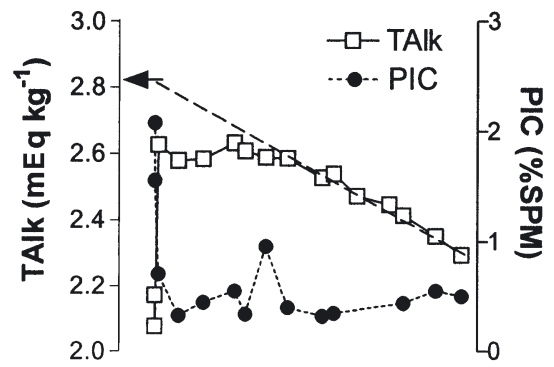

(C)

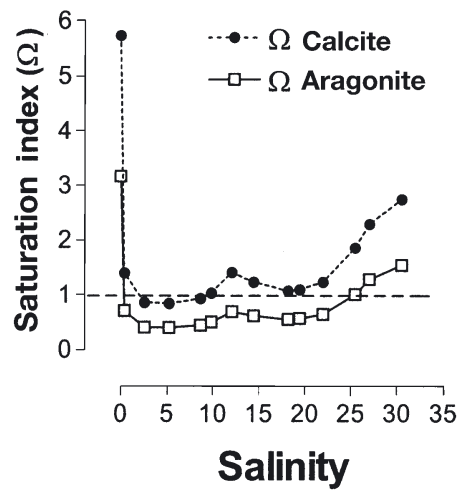

Fig. 4. Distributions of (A) dissolved inorganic carbon (DIC; mmol kg-1); (B) total alkalinity (TAlk, mEq kg-1) and particulate inorganic carbon (PIC, in \% suspended particulate matter $[\mathrm{SPM}])$; and $(\mathrm{C})$ the saturation index $(\Omega)$ for calcite and aragonite, as a function of salinity in the Loire estuary in September 1998 
to ammonification and nitrification (Abril \& Frankignoulle 2001). Consequently, such a huge production of alkalinity can only be attributed to carbonate dissolution, which is confirmed here by the significant decrease of PIC from the river to the estuary. This is also consistent with the sediments study of Négrel (1997), who observed a calcium depletion of $50 \%$ in estuarine sediments relative to fluviatile sediments. In the estuarine waters, our calculated carbonate saturation states show a large undersaturation for aragonite, but only a slight undersaturation (minimum $\Omega=0.84$ ) for calcite in the 0 to 10 salinity region (Fig. $4 \mathrm{C}$ ). In Canadian shelf sediments, Mucci et al. (2000) made similar observations with calculated $\Omega$ values for calcite in porewaters always higher than 0.8 and often above 1, but still the occurrence of carbonate dissolution unequivocally demonstrated by a net $\mathrm{Ca}^{2+}$ release to porewaters. In the case of the Loire estuary, the occurrence of intense carbonate dissolution at a relatively high theoretical saturation state might also be due to the presence of fluviatile authigenic calcite (Grosbois et al. 2001), whose solubility has not yet been documented (Morse \& Arvidson 2002).

Carbonate dissolution is a chemical process driven by thermodynamic potential, which depends on physico-chemical conditions of both the water and the solid phases. Among the major parameters in the water phase conditioning the occurrence and intensity of carbonate dissolution are $\mathrm{pH}, \mathrm{pCO}_{2}$, ionic strength, and the presence of 'foreign ions' and $\mathrm{Ca}^{2+}$ concentration (Morse \& Arvidson 2002). At the Loire river-estuary transition (low salinity region), changes in the physicochemical conditions driven by biogeochemical processes, that is by the sharp autotrophy > heterotrophy switch and subsequent changes in $\mathrm{pH}$ and $\mathrm{pCO}_{2}$, are by far the dominant factors for the occurrence of car- bonate dissolution (Figs. $3 \& 4$ ). This was also the case in the Ems estuary, where, by contrast to the Loire, carbonate suspensions are mainly seaborne, but also are dissolved in the MTZ, where $\mathrm{pH}$ is much lower than in the marine area (de Jonge \& Villerius 1989). In coastal and marine sediments the biogeochemical factors that control carbonate dissolution are now well understood. Aerobic respiration that produces carbonic acid $\left(\mathrm{CO}_{2}\right.$ $+\mathrm{H}_{2} \mathrm{O}=\mathrm{H}_{2} \mathrm{CO}_{3}$ ) promotes carbonate dissolution, whereas most anaerobic processes (Fe[III] and $\mathrm{SO}_{4}$ reductions), consume protons and lead to a build-up of alkalinity in the porewaters, inhibiting dissolution and sometimes resulting in precipitation (Morse \& Mackenzie 1990, Mucci et al. 2000). In addition, the oxidation by oxygen of reduced compounds (ammonia, dissolved iron and sulphides) generates acid (protons), and also stimulates dissolution (Aller 1982, Green \& Aller 1998). Estuarine MTZs are sites of intense exchanges of chemical compounds between the particulate and dissolved phases through chemical reactions and adsorption/desorption processes (Van Beusekom \& de Jonge 1994). Due to strong tidal currents, particles remain in suspension in the water column under oxic conditions. Anoxic conditions occur in the most concentrated layers of fluid mud but are restricted to short periods, typically $\sim 5$ d (Abril et al. 1999, Le Normant 2000). In addition, the periodic resuspensions of the fluid mud prevent carbonate particles from staying in contact with highly alkaline porewater and allow complete oxidation of reduced compounds. This makes the estuarine MTZ fluid-mud system an efficient biogeochemical reactor for carbonate dissolution.

Using a mixing model based on rare earth-element analysis in Loire estuarine suspensions, Négrel (1997) showed that the proportion of fluviatile suspensions in the estuary represented 80 to $90 \%$ all along the first

Table 1. Typical particulate organic and inorganic carbon concentrations (POC and PIC, respectively, expressed as \% of suspended particulate matter [SPM]) in the Loire riverine and estuarine suspensions. Yearly average (discharge weighed) concentrations are calculated using the reported summer and winter values and the corresponding solid discharges from Meybeck et al. (1988)

\begin{tabular}{|lcccc|}
\hline & Summer & $\begin{array}{c}\text { Riverine suspensions } \\
\text { Winter }\end{array}$ & Yearly average & Estuarine suspensions \\
Summer
\end{tabular}


$50 \mathrm{~km}$ in the upper estuary and then decreased to reach 40 to $50 \%$ at the estuarine mouth. This large predominance of fluviatile suspensions in the upper estuary allows us to interpret quantitatively the changes in particulate concentrations between the river non-tidal station and the upstream estuarine stations in the MTZ as the result of biogeochemical processes (particulate carbon removal), rather than particle mixing. Table 1 summarizes the typical POC and PIC concentrations reported so far in the Loire river and estuary during high and low discharge regimes. These carbon concentrations show a remarkable constancy with time, suggesting that little has changed in the eutrophication status of the Loire since the mid-1980s. Previous studies, either process-based, including respiration and primary production measurements (Billen et al. 1986, Relexans et al. 1988), or based on geochemical considerations of changes in carbon concentrations at the river-estuary transition (Meybeck et al. 1988) lead to the same conclusion of a complete mineralization of the riverine algal-POC in the estuarine MTZ. Indeed, the constant POC concentration found at any season in the Loire MTZ (3.5\%; Table 1) corresponds to the 'detrital-POC', originating from soils, that is supplied during high river discharges, and is refractory to bacterial decomposition at the scale of its residence time in the estuary (Meybeck et al. 1988). A similar statement can be made with the PIC data in Table 1. Indeed, the total PIC we measured during our cruise in river suspensions $(2.1 \%)$ exactly matches values reported previously during the same late summer period, among which ca. $1.7 \%$ is authigenic PIC and $0.4 \%$ is detrital PIC (Manickam et al. 1985, Meybeck et al. 1988, Grosbois et al. 2001). Thus, the residual value we measured in the MTZ $(0.4 \%)$ corresponds to the detrital PIC in river suspensions, which strongly suggests that (similarly to algal-POC) only authigenic PIC was lost at the river-estuary transition, detrital PIC (similarly to detrital POC) having a conservative behaviour. This would imply that the authigenic PIC precipitated in the river is more soluble than detrital PIC mechanically eroded from the basin. Dissolution kinetics studies are now required to confirm this hypothesis.

\section{Coupling between aerobic respiration and carbonate dissolution}

The data we collected during this study can be used to develop a stoichiometric approach in order to assess the coupling between aerobic respiration and carbonate dissolution in estuarine MTZ. Relexans et al. (1988) showed that, because light penetration $(<1 \%$ incident light) in the Loire estuary is only 30 to $50 \mathrm{~cm}$, i.e. $<5 \%$ of the water column, primary production represented less than $5 \%$ of heterotrophic activity all year round. It thus appears reasonable to assume that dark processes dominate and that the respiratory quotient is equal to 1. In addition, during our cruise measured respiration rates were $\sim 0.5 \mu \mathrm{mol} \mathrm{l}^{-1} \mathrm{~h}^{-1}$ (R. Wollast pers. comm.), dark ammonia uptake was $\sim 0.1 \mu \mathrm{mol} \mathrm{l}^{-1} \mathrm{~h}^{-1}$ (Middelburg \& Nieuwenhuize 2000) and the C:N ratio of particulate organic matter was 6 to 7 (J. J. Middelburg pers. comm.). When assuming the same $\mathrm{C}: \mathrm{N}$ ratio for the organic matter being decomposed, this means that $70 \%$ of the ammonium produced by ammonification is immediately re-incorporated into bacterial biomass in an organic form, thus having no effect on alkalinity. In addition, it implies that nitrification becomes a minor oxygen consuming process. For those reasons, we assume that aerobic respiration is the only process consuming oxygen, and we use a simplified formulation of organic matter that takes into account only carbon. Accordingly, the stoichiometry of aerobic respiration and carbonate dissolution are represented by, respectively:

$$
\mathrm{CH}_{2} \mathrm{O}^{\prime}+\mathrm{O}_{2} \rightarrow \mathrm{CO}_{2}+\mathrm{H}_{2} \mathrm{O}
$$

and

$$
\mathrm{CO}_{2}+\mathrm{H}_{2} \mathrm{O}+\mathrm{CaCO}_{3} \rightarrow 2 \mathrm{HCO}_{3}{ }^{-}+\mathrm{Ca}^{2+}
$$

where ' $\mathrm{CH}_{2} \mathrm{O}$ ' represents organic carbon.

Only a fraction, $\alpha$, of the carbonic acid generated by respiration is involved into the carbonate dissolution reaction, which can be written as:

$$
\begin{gathered}
\mathrm{CH}_{2} \mathrm{O}^{\prime}+\mathrm{O}_{2}+\alpha \mathrm{CaCO}_{3} \rightarrow \\
(1-\alpha) \mathrm{CO}_{2}+(1-\alpha) \mathrm{H}_{2} \mathrm{O}+2 \alpha \mathrm{HCO}_{3}{ }^{-}+\alpha \mathrm{Ca}^{2+}
\end{gathered}
$$

with $0 \leq \alpha \leq 1$. When considering a closed system, where no gaseous exchange occurs with the atmosphere, we can write from the dissolution reaction:

$$
(1-\alpha) \Delta \mathrm{AOU}_{(\mathrm{cl})}=\Delta \mathrm{ECO}_{2(\mathrm{cl})}
$$

and

$$
2 \alpha \Delta \mathrm{DIC}_{(\mathrm{cl})}=(1+\alpha) \Delta \mathrm{TAlk}
$$

where $\Delta$ is the variation of a given chemical species and the ' $\mathrm{Cl}^{\prime}$ notation refers to a closed system. TAlk is not affected by gaseous exchange, consequently $\Delta$ TAlk is identical in closed and open systems.

To investigate the magnitude of a given process in estuaries, one classical approach is to compare the observed profiles as a function of salinity with the theoretical mixing line between 2 given end-members. When making the hypothesis that end-members are constant at the timescale of estuarine mixing, the variation, $\Delta$, of the parameter is the difference between the observed value and the value predicted by the conservative line at the same salinity. Owing to the low discharge condition during our cruise, which makes the steady-state hypothesis 
Table 2. Linear regression parameters. Slopes and intercepts are given \pm SE. $\Delta \mathrm{ECO}_{2}: \Delta$ excess carbon dioxide; $\Delta \mathrm{AOU}: \Delta$ apparent oxygen utilisation; $\Delta$ TAlk: $\Delta$ total alkalinity; $\Delta$ DIC: $\Delta$ dissolved inorganic carbon. $\Delta$ refers to the difference relative to conservative mixing in the respective sections (see 'Discussion'). p-values: probability for the slope to be different from 0 ; ns: not significant

\begin{tabular}{|lcc|}
\hline & Salinity $0-12$ & Salinity 12-33 \\
\hline$\Delta \mathrm{ECO}_{2}$ vs $\Delta \mathrm{AOU}$ & Significant & Significant \\
Slope & $1.71 \pm 0.16$ & $0.92 \pm 0.11$ \\
$y$-intercept & $-8.31 \pm 10.85$ & $0.16 \pm 7.76$ \\
$\mathrm{R}^{2}$ & 0.965 & 0.926 \\
$\mathrm{p}$ & 0.0005 & 0.0005 \\
$\Delta$ TAlk vs $\Delta$ DIC & Significant & $\mathrm{ns}$ \\
Slope & $1.18 \pm 0.03$ & \\
$y$-intercept & $-6.43 \pm 6.88$ & \\
$\mathrm{R}^{2}$ & 0.997 & 0.523 \\
$\mathrm{p}$ & $<0.0001$ & 0.0661 \\
\hline
\end{tabular}

acceptable, we performed such calculations for AOU, $\mathrm{ECO}_{2}$, DIC and TAlk, using first a dilution line between the riverine and the marine end-members. When using these 2 end-members, we obtained a highly significant linear correlation $\left(\mathrm{R}^{2}=0.97\right)$ between $\Delta \mathrm{DIC}$ and $\Delta \mathrm{TAlk}$, but a weak correlation $\left(\mathrm{R}^{2}=0.49\right)$ between $\Delta \mathrm{ECO}$ and $\triangle \mathrm{AOU}$ (not shown). We then considered separately the 2 regions showing an oxygen minimum and a $\mathrm{pCO}_{2}$ maximum (Fig. 3) by introducing an intermediate end-member at a salinity of 12, and we obtained significantly different relationships, listed in Table 2 and shown in Fig. 5. In the upper estuary (salinities of 0 to 12 ), the slope between $\triangle \mathrm{AOU}$ and $\triangle \mathrm{ECO}_{2}$ is 1.71 and is significantly higher than $1(\mathrm{p}<0.0001)$ This is in agreement with the occurrence of calcite dissolution coupled to aerobic respiration and implies that $\alpha \neq 0$. In addition, the slope between $\Delta \mathrm{DIC}$ and $\Delta \mathrm{TAlk}$ is 1.18 and is significantly higher than $1(\mathrm{p}=0.001)$. This is consistent with a calcite dissolution that involves only a fraction of the $\mathrm{CO}_{2}$ generated by aerobic respiration, and implies that $\alpha<1$. In the lower estuary (salinities of 12 to 33), $\triangle \mathrm{AOU}$ and $\Delta \mathrm{ECO}_{2}$ are similar (the slope of the regression line was not significantly different from 1 , with $\mathrm{p}=0.058$ ), in agreement with the occurrence of aerobic respiration alone $(\alpha=0)$. In addition, $\Delta \mathrm{DIC}$ and $\Delta \mathrm{TAlk}$ show no correlation, TAlk being almost conservative ( $\Delta$ TAlk $\sim 0$ ), also consistent with aerobic respiration alone occurring in this area. None of the regressions had significant intercepts $(\mathrm{p}>$ 0.05).

Calcite dissolution appears to occur only in the low salinity (0 to 12 ) region of the estuary, with the following relationships from Table 2:

$$
\begin{array}{ll}
\Delta \mathrm{AOU}_{(\text {op })}=\mathrm{a}_{1} \Delta \mathrm{ECO}_{2}(\text { op) } & \text { with } \mathrm{a}_{1}=1.71 \pm 0.16 \\
\Delta \mathrm{DIC}_{(\mathrm{op})}=\mathrm{a}_{2} \Delta \mathrm{TALK} & \text { with } \mathrm{a}_{2}=1.18 \pm 0.03
\end{array}
$$
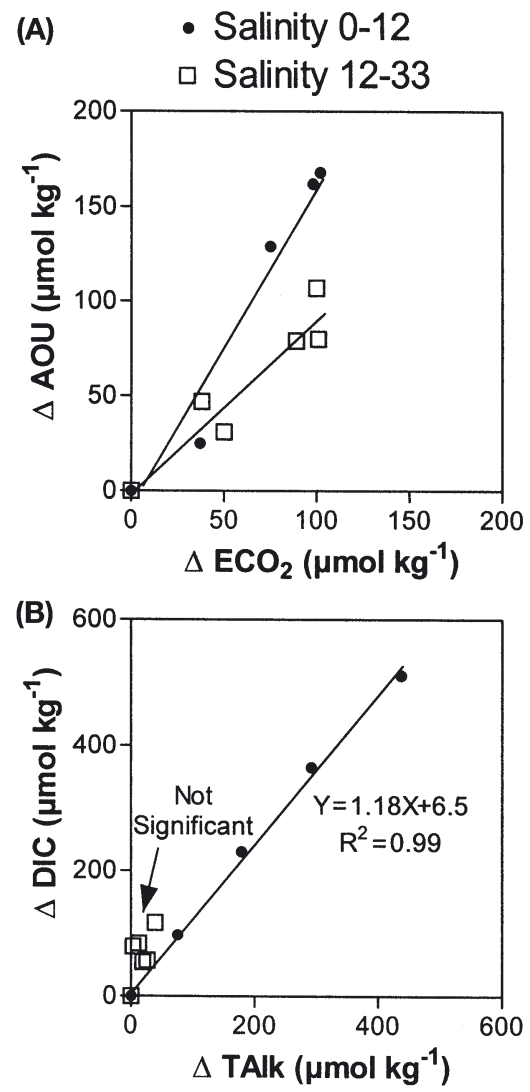

Fig. 5. Relationships between (A) $\Delta$ apparent oxygen utilisation $(\Delta \mathrm{AOU})$ and $\Delta$ excess carbon dioxide $\left(\Delta \mathrm{ECO}_{2}\right)$; and (B) $\Delta$ dissolved inorganic carbon $(\Delta \mathrm{DIC})$ and $\Delta$ total alkalinity ( $\triangle$ TAlk). Two sections of the estuary were considered separately (Salinities 0 to 12 and 12 to 33 ). $\Delta$ refers to the difference relative to conservative mixing in the respective sections (see 'Discussion')

where the notation 'op' refers to an open system that exchanges gas with the atmosphere.

Because $\mathrm{ECO}_{2}$ and $\mathrm{AOU}$ are of the same order of magnitude, and because the exchange coefficients of $\mathrm{CO}_{2}$ and $\mathrm{O}_{2}$ are also similar (Wanninkhof 1992), these 2 gases exchange with the atmosphere at a similar rate. The differences in concentrations between open and closed systems correspond to the loss to the atmosphere, and are thus very close for $\mathrm{ECO}_{2}$ and for AOU:

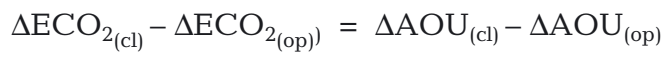

Using Eqs. (1) \& (3) this leads to:

$$
\Delta \mathrm{ECO}_{2_{(\mathrm{cl})}}\left[1-\frac{1}{1-\alpha}\right]=\Delta \mathrm{ECO}_{2_{(\mathrm{op})}}\left[1-\mathrm{a}_{1}\right]
$$

That is rewritten as:

$$
\Delta \mathrm{ECO}_{2_{(\mathrm{cl})}}=\left(\mathrm{a}_{1}-1\right)\left[\frac{1-\alpha}{\alpha}\right] \Delta \mathrm{ECO}_{2_{(\text {op })}}
$$

Similarly, the term $\Delta$ TAlk can be removed from Eqs. (2) \& (4) to obtain the following relationship: 


$$
\Delta \mathrm{DIC}_{(\mathrm{cl})}=\frac{1}{\mathrm{a}_{2}}\left[\frac{1+\alpha}{2 \alpha}\right] \Delta \mathrm{DIC}_{(\mathrm{op})}
$$

The exchange of DIC with the atmosphere concerns the $\mathrm{CO}_{2}$ form only, so the differences between open and closed systems, that is the quantity exchanged with the atmosphere, are equal for DIC and $\mathrm{ECO}_{2}$. Consequently, the 2 coefficients in Eqs. (5) \& (6) are equal, and thus:

$$
\left(\mathrm{a}_{1}-1\right)\left[\frac{1-\alpha}{\alpha}\right]=\frac{1}{\mathrm{a}_{2}}\left[\frac{1+\alpha}{2 \alpha}\right]
$$

and

$$
\alpha=\frac{2 \mathrm{a}_{2}-2 \mathrm{a}_{1} \mathrm{a}_{2}+1}{2 \mathrm{a}_{2}-2 \mathrm{a}_{1} \mathrm{a}_{2}-1}
$$

which leads to a numerical value of $\alpha=0.25 \pm 0.09$. Approximately $25 \%$ of the $\mathrm{CO}_{2}$ generated by respiration is involved in calcite dissolution. In addition, it is possible to estimate the fraction of the produced $\mathrm{CO}_{2}$ that has escaped to the atmophere using Eq. (6):

$$
\Delta \mathrm{DIC}_{(\mathrm{cl})}=2.1 \Delta \mathrm{DIC}_{(\mathrm{op})}
$$

Approximately $52 \%$ of the $\mathrm{CO}_{2}$ produced by respiration had already escaped to the atmosphere. This confirms the fast and dynamic coupling between $\mathrm{CO}_{2}$ generation and evasion reported by previous DIC studies in estuaries (Frankignoulle et al. 1996, 1998, Cai et al. 1999, 2000, Raymond et al. 2000).

\section{A tentative summer budget of $\mathrm{CO}_{2}$ for the Loire estuary}

To estimate the total $\mathrm{CO}_{2}$ emissions from the estuary, we considered a gas exchange coefficient of $13 \mathrm{~cm} \mathrm{~h}^{-1}$ as representative for macrotidal estuaries (Frankignoulle et al. 1996), and we integrated the calculated fluxes over the surface of $5 \mathrm{~km}$ sections of the Loire estuary. This lead to fluxes between 30 and $280 \mathrm{mmol} \mathrm{m}^{-2} \mathrm{~d}^{-1}$, and a total emission of $110 \mathrm{tC} \mathrm{d}^{-1}$ from the entire estuary, which ranks the Loire among the European estuaries with highest $\mathrm{CO}_{2}$ emissions

Table 3. Tentative carbon dioxide budget for the Loire estuary during summer. See 'Discussion' for numbers selection

\begin{tabular}{|lcr|}
\hline & $\begin{array}{c}\text { Sources } \\
\left(\mathrm{tC} \mathrm{d}^{-1}\right)\end{array}$ & $\begin{array}{c}\text { Sinks } \\
\left(\mathrm{t} \mathrm{C} \mathrm{d}^{-1}\right)\end{array}$ \\
\hline Respiration & 150 & \\
Atmospheric emission & & 110 \\
Primary production & & 10 \\
Carbonate dissolution & 150 & 30 \\
Total & & 150 \\
\hline
\end{tabular}

after the highly polluted Scheldt (Frankignoulle et al. 1998). The heterotrophic activity in the Loire estuary during summer is well documented by the different approaches, giving very similar results: $150 \mathrm{tC} \mathrm{d}^{-1}$ when simply considering that all the riverine algal POC is consumed (Meybeck et al. 1988), $150 \mathrm{tC} \mathrm{d}^{-1}$ when using bacterial production (thymidine incorporation) and growth yield (Relexans et al. 1988), and $160 \mathrm{tC} \mathrm{d}^{-1}$ during spring tide when using biological oxygen demand and a model of suspended matter dynamics (Thouvenin et al. 1994). Due to light limitation, primary production in the Loire estuary is known to be a very minor component of the carbon cycle, representing about $10 \mathrm{tC} \mathrm{d}^{-1}$ (Relexans et al. 1988). Carbonate dissolution can be estimated either by considering that all the riverine autigenic PIC summer input is dissolved $\left(23 \mathrm{tC} \mathrm{d}^{-1}\right.$; Meybeck et al. 1988) or by multiplying $1 / 2$ of the TAlk increase $\left(360 \mathrm{mmol} \mathrm{\textrm {kg } ^ { - 1 }}\right.$ ) with the river discharge during the cruise $\left(220 \mathrm{~m}^{3} \mathrm{~s}^{-1}\right)$, which results in $80 \mathrm{tC} \mathrm{d}^{-1}$. Using an intermediate value of $30 \mathrm{tC} \mathrm{d}^{-1}$ allows an equilibration of the $\mathrm{CO}_{2}$ budget (Table 3) in which $20 \%$ of the respiratory $\mathrm{CO}_{2}$ is involved in carbonate dissolution. Notwithstanding the large uncertainties probably still remaining with these numbers, we believe they satisfactorily reflect the significance of carbonate dissolution in the Loire estuary during summer.

As a conclusion, we can define here a 'reverse buffering mechanism' with respect to atmospheric $\mathrm{CO}_{2}$ exchange along the eutrophic Loire river-estuary continuum: in the river, intense primary production consumes atmospheric $\mathrm{CO}_{2}$ but also creates conditions for calcite precipitation that releases $\mathrm{CO}_{2}$, thus buffering the $\mathrm{CO}_{2}$ influx; in the estuarine MTZ, intense respiration produces atmospheric $\mathrm{CO}_{2}$ but also results in an almost complete dissolution of the calcite produced upstream, thus consuming water $\mathrm{CO}_{2}$ and buffering the $\mathrm{CO}_{2}$ outflux. For future biogeochemical studies in estuaries, calcite precipitation and dissolution might be considered as important processes for the carbon cycle. Furthermore, detailed distributions of $\mathrm{Ca}^{2+}$ and $\mathrm{Mg}^{2+}$ may provide significant information for the carbonate system of estuaries.

Acknowledgements. This work was funded by the European Commission in the framework of the BIOGEST project (ENV4-CT96-0213). We thank the municipality of Paimbeuf, which kindly provided laboratory space, and the crew of the RV 'Côte de la Manche' (INSU, France) for their assistance during the cruise. We are particularly thankful to Emile Libert for his technical support. We thank P. Anshutz for critically reading an early draft of the manuscript as well as J. P. Gattuso and 3 anonymous referees for their constructive comments. G.A. was funded by the European Community (grant ENV4-CT98-5119), M.F. is a research associate of the FNRS (Belgium). 


\section{LITERATURE CITED}

Abril G, Frankignoulle M (2001) Nitrogen-alkalinity interactions in the highly polluted Scheldt basin (Belgium). Water Res 35:844-850

Abril G, Etcheber H, Le Hir P, Bassoullet P, Boutier B, Frankignoulle M (1999) Oxic/anoxic oscillations and organic carbon mineralization in an estuarine maximum turbidity zone (The Gironde, France). Limnol Oceanogr 44:1304-1315

Abril G, Nogueira M, Etcheber H, Cabeçadas G, Lemaire E, Brogueira MJ (2002) Behaviour of organic carbon in nine contrasting European estuaries. Estuar Coast Shelf Sci 54: 241-262

Aller R (1982) Carbonate dissolution in nearshore terrigenous muds: the role of physical and biological reworking. J Geol 90:79-95

Benson BB, Krause D (1984) The concentration and isotopic fractionation of oxygen dissolved in freshwater and seawater in equilibrium with the atmosphere. Limnol Oceanogr 29:620-632

Billen G, Cauwet G, Dessery S, Meybeck M, Somville M (1986) Origine et comportement du carbone organique dans l'estuaire de la Loire. Rapp P-V Réun Cons Int Explor Mer 186:375-391

Borges AV, Frankignoulle M (2002) Distribution and air-water exchange of carbon dioxide in the Scheldt plume off the Belgium coast. Biogeochemistry 59:41-67

Brasse S, Reimer A, Seifert R, Michaelis W (1999) The influence of intertidal mudflats on the dissolved inorganic carbon and total alkalinity distribution in the German Bight, southeastern North Sea. J Sea Res 42:93-103

Brewer PG, Goldman JC (1976) Alkalinity changes generated by phytoplankton growth. Limnol Oceanogr 21:108-117

Cai WJ, Pomeroy LR, Moran MA, Wang Y (1999) Oxygen and carbon dioxide mass balance for the estuarine-intertidal marsh complex of five rivers in the southeastern US. Limnol Oceanogr 44:639-649

Cai WJ, Wiebe WJ, Wang Y, Sheldon JE (2000) Intertidal marsh as a source of dissolved inorganic carbon and a sink of nitrate in the Satilla River-estuarine complex in the southeastern US. Limnol Oceanogr 45:1743-1752

de Jonge VN, Villerius LA (1989) Possible role of carbonate dissolution in estuarine phosphate dynamics. Limnol Oceanogr 34:332-340

Frankignoulle M, Bourge I, Wollast R (1996) Atmospheric $\mathrm{CO}_{2}$ fluxes in a highly polluted estuary (The Scheldt). Limnol Oceanogr 41:365-369

Frankignoulle M, Abril G, Borges A, Bourge I, Canon C, Delille B, Libert E, Théate JM (1998) Carbon dioxide emission from European estuaries. Science 282:434-436

Gallenne B (1974) Les accumulations turbides de l'estuaire de la Loire. Etude de la Crème de vase. PhD thesis, Nantes University, Nantes

Gattuso JP, Frankignoulle M, Wollast R (1998) Carbon and carbonate metabolism in coastal aquatic ecosystems. Annu Rev Ecol Syst 29:405-434

Green MA, Aller RC (1998) Seasonal patterns of carbonate diagenesis in nearshore terrigenous muds: relation to spring phytoplankton bloom and temperature. J Mar Res 56 1097-1124

Grosbois C, Négrel P, Fouillac C, Grimaud D (2000) Dissolved load of the Loire River: chemical and isotopic characterization. Chem Geol 170:179-201

Grosbois C, Négrel P, Grimaud D, Fouillac C (2001) An overview of dissolved and suspended matter fluxes in the Loire river basin: natural and anthropogenic inputs. Aquat Geochem 7:81-105
Hoppema JMJ (1990) The distribution and seasonal variations of alkalinity in the southern bight of the North Sea and in the Western Wadden Sea. Neth J Sea Res 26:11-23

Ittekkot V, Lanne RWPM (1991) Fate of riverine particulate organic matter. In: Degens ET, Kempe S, Richey R (eds) Biogeochemistry of major world rivers. Scientific Committee on Problems of the Environment (SCOPE) 42. John Wiley \& Sons, New York, NY, p 233-242

Jones JB, Mulholland PJ (1998) Carbon dioxide variation in a hardwood forest stream: an integrative measure of whole catchment soil respiration. Ecosystems 1:183-196

Le Normant C (2000) Three-dimensional modelling of cohesive sediment transport in the Loire estuary. Hydrol Process 14:2231-2243

Lyman J (1975) Buffer mechanism of seawater. PhD thesis, University of California, Los Angeles, CA

Manickam S, Barbaroux L, Ottmann F (1985) Composition and mineralogy of suspended sediment in the fluvio-estuarine zone of the Loire river, France. Sedimentology $32: 721-741$

Mantoura RFC, Woodward EMS (1983) Conservative behaviour of riverine dissolved organic carbon in the Severn Estuary: chemical and geochemical implications. Geochim Cosmochim Acta 47:1293-1309

Mehrbach C, Culberson C, Hawley JE, Pytkowich RM (1973) Measurements of the apparent dissociation constants of carbonic acid in seawater at atmospheric pressure. Limnol Oceanogr 18:897-907

Meybeck M (1993a) Riverine transport of atmospheric carbon: sources, global typology and budget. Water Air Soil Pollut 70:443-463

Meybeck M (1993b) C, N, P and S in rivers: from sources to global inputs. In: Wollast R, Mackenzie FT, Chou L (eds) Interactions of $\mathrm{C}, \mathrm{N}, \mathrm{P}$ and $\mathrm{S}$ biogeochemical cycles and global change. NATO ASI Series, Vol 14. Springer-Verlag, Berlin, p 163-191

Meybeck M, Cauwet G, Dessery S, Somville M, Gouleau D, Billen G (1988) Nutrients (organic C, P, N, Si) in the eutrophic river Loire and its estuary. Estuar Coast Shelf Sci 27:595-624

Middelburg JJ, Nieuwenhuize J (2000) Uptake of dissolved inorganic nitrogen in turbid, tidal estuaries. Mar Ecol Prog Ser 192:79-88

Middelburg JJ, Nieuwenhuize J (2001) Nitrogen isotope tracing of dissolved inorganic nitrogen behaviour in tidal estuaries. Estuar Coast Shelf Sci 53:385-391

Migniot C (1993) Bilan de l'hydrologie et de l'hydrosédimentaire de l'estuaire de la Loire au cours des deux dernières décénnies. Association pour la Protection de l'Environnement de l'Estuaire de la Loire, Port Autonome de Nantes-St Nazaire, Nantes

Morse JW, Arvidson RS (2002) The dissolution kinetics of major sedimentary carbonate minerals. Earth Sci Rev 58:51-84

Morse JW, Mackenzie FT (1990) Geochemistry of sedimentary carbonates. Developments in Sedimentology. Elsevier, Amsterdam

Mucci A (1983) The solubility of calcite and aragonite in seawater at various salinities, temperature, and one atmosphere total pressure. Am J Sci 283:780-799

Mucci A, Sundby B, Gehlen M, Arakaki T, Zhong S, Silverberg $N(2000)$ The fate of carbon in continental shelf sediments of eastern Canada: a case study. Deep-Sea Res II 47: $733-760$

Négrel P (1997) Multi-element chemistry of Loire estuary sediments: anthropogenic vs natural sources. Estuar Coast Shelf Sci 44:395-410

Raymond PA, Bauer JE (2001) DOC cycling in a temperate 
estuary: a mass balance approach using natural ${ }^{14} \mathrm{C}$ and ${ }^{13} \mathrm{C}$ isotopes. Limnol Oceanogr 46:655-667

Raymond PA, Bauer JE, Cole JJ (2000) Atmospheric $\mathrm{CO}_{2}$ evasion, dissolved inorganic carbon production, and net heterotrophy in the York River estuary. Limnol Oceanogr 45: 1707-1717

Relexans JC, Meybeck M, Billen G, Brugeaille M, Etcheber $\mathrm{H}$, Somville M (1988) Algal and microbial processes involved in particulate organic matter dynamics in the Loire estuary. Estuar Coast Shelf Sci 27, 625-644

Smith SV, Hollibaugh JT (1993) Coastal metabolism and the oceanic organic carbon cycle. Rev Geophys 31:75-89

Thouvenin B, Le Hir P, Romaña LA (1994) Dissolved oxygen model in the Loire estuary. In: Dyer KR, Orth RJ (eds) Changes in fluxes in estuaries: implications from science

Editorial responsibility: Otto Kinne (Editor),

Oldendorf/Luhe, Germany to management. Olsen \& Olsen, Fredensborg, p 169-178

Van Beusekom JEE, Jonge de VN (1994) The role of suspended matter in the distribution of dissolved inorganic phosphate, iron and aluminium in the Ems estuary. Neth J Aquat Ecol 28:383-395

Wanninkhof R (1992) Relationship between wind speed and gas exchange over the ocean. J Geophys Res 97(C5): 7373-7382

Weiss RF (1974) Carbon dioxide in water and seawater: the solubility of a non-ideal gas. Mar Chem 2:203-215

Wollast R (1983) Interactions in estuaries and coastal waters. In: Bolin B, Cook RB (eds) The major biogeochemical cycles and their interactions. Scientific Committee on Problems of the Environment (SCOPE). John Wiley \& Sons, New York, NY, p 385-407

Submitted: May 6, 2002; Accepted: May 8, 2003

Proofs received from author(s): August 29, 2003 